\title{
Immunological changes among farmers exposed to phenoxy herbicides: preliminary observations
}

Local Health Unit,

Tarquinia (VT), Italy A Faustini

Istituto Superiore di Sanita', Rome, Italy, and Department of Occupational and

Environmental

Medicine, Linköping,

Sweden

L Settim

Istituto Superiore di

Sanita', Rome, Italy

R Pacifici

P Zuccaro

Epidemiologic Unit, Lazio Regional Health Authority, Rome, Italy $\checkmark$ Fano

F Forastiere

Correspondence to:

Laura Settimi, Laboratorio

di Igiene Ambientale, Istituto

Superiore di Sanita', Viale

Regina Elena 299, 00161

Roma, Italia.

Accepted 10 May 1996

\author{
Annunziata Faustini, Laura Settimi, Roberta Pacifici, Valeria Fano, Piergiorgio Zuccaro, \\ Francesco Forastiere
}

\begin{abstract}
Objectives-To evaluate short term immunological changes after agricultural exposure to commercial formulations of chlorophenoxy herbicides.

Methods-Blood samples were collected from 10 farmers within seven days before exposure, one to 12 days after exposure, and again 50 to 70 days after exposure. Whole blood was used to count lymphocyte subsets with monoclonal antibodies. Peripheral blood mononuclear (PBM) cells were used to measure natural killer (NK) cell activity and lymphocyte response to mitogenic stimulations. Values before exposure were used as reference.

Results-In comparison with concentrations before exposure, a significant reduction was found one to 12 days after exposure in the following variables $(P<0.05)$ : circulating helper (CD4) and suppressor T cells (CD8), CD8 dim, cytotoxic $T$ lymphocytes (CTL), natural killer cells (NK), and CD8 cells expressing the surface antigens HLA-DR (CD8-DR), and lymphoproliferative response to mitogen stimulations. All immunological values found 50-70 days after exposure were comparable with concentrations before exposure, but mitogenic proliferative responses of lymphocytes were still significantly decreased.

Conclusions-According to our data agricultural exposure to commercial 2,4-dichlorophenoxyacetic acid (2,4-D) and 4-chloro-2-methylphenoxyacetic acid (MCPA) formulations may exert short term immunosuppressive effects. Further studies should clarify whether the immunological changes found may have health implications and can specifically contribute to cancer aetiology.
\end{abstract}

(Occup Environ Med 1996;53:583-585)

Keywords: immunological changes; farmers; phenoxy herbicides

Agricultural exposure to phenoxy herbicides has been associated with increased risk of nonHodgkin's lymphoma (NHL), and less consistently, increased risk of soft tissue sarcoma. ${ }^{1-7}$ As striking excesses of non-Hodgkin's lymphoma have been well documented in association with immunological disorders or immunosuppressive treatment, ${ }^{8}$ some authors have recently suggested that phenoxy herbicides might cause this type of cancer by altering the function of lymphocytes. ${ }^{910}$

A few experimental studies have been carried out in mice with purified derivatives and commercial formulations of 2,4-dichlorophenoxyacetic acid $(2,4-\mathrm{D})$, an active ingredient used extensively to control broad leaf weeds. The results from these investigations showed a variety of immunological alterations: $B$ and $T$ lymphocyte proliferative responses were enhanced after subacute dermal exposure and acute oral exposure to derivatives of $2,4-\mathrm{D}$, whereas in utero exposure to $2,4-\mathrm{D}$ ester produced a reduction of lymphocyte mitogen responses, ${ }^{11-13}$ alterations of urethane induced pulmonary adenoma were also found after exposure to a commercial formulation of 2,4$\mathrm{D}$, suggesting a mild cancer promoting activity of these products by means of alterations of cell mediated immune function. ${ }^{1014}$

At present, no data are available on immunological effects of phenoxy herbicides on humans. In this article we report the results of a study evaluating short term effects of agricultural exposures to phenoxy herbicides on human peripheral blood lymphocytes.

\section{Materials and methods}

SUBJECTS

The study included 10 farmers, mean (SD) age 44.0 (9.1) years, who mixed and applied chlorophenoxy herbicides during March 1994, for one to three days. All farmers used commercial formulations containing 2,4-D and 4chloro-2-methylphenoxyacetic acid (MCPA). The mean (range) quantity of herbicides applied was $39 \cdot 1(12-155) \mathrm{kg}$.

\section{BLOOD SAMPLING AND IMMUNOLOGICAL}

ANALYSES

Blood samples were collected and analysed within seven days before exposure to herbicides, within one to 12 days after exposure, and within 50-70 days after exposure. During the study period the farmers were not exposed to other pesticides. Blood samples were obtained in EDTA vacutainer tubes and were analysed within two hours after phebotomy. Complete blood profile and count was obtained from each subject. Whole blood was used to count lymphocyte subsets with commercial monoclonal antibodies (CD4FITC/HLA-DR-PE; CD8-FITC/HLA-DRPE; CD3-PE/CD16-CD56-FITC). Stained and fixed lymphocytes were analysed with an Ortho Cytoron Absolute 4 flow cytometer. 
Peripheral blood mononuclear (PBM) cells were separated from blood by density gradient centrifugation. The PBM cells were used to measure natural killer (NK) cell mediated cytotoxicity by a $\left[{ }^{51} \mathrm{Cr}\right.$ ] release assay. ${ }^{15}$ The data were expressed as lytic units $20\left(\mathrm{LU}_{20}\right) / 10^{7}$ effector cells. ${ }^{16}$ To evaluate lymphocyte proliferative response, PBM cells were washed and suspended in tissue culture medium (RPMI 1640 with $10 \%$ heat inactivated fetal calf serum, L-glutamine, and penicillin/streptomycin). Cells were stimulated with different doses of phytohaemagglutinin (PHA) and concavalin A (ConA). Tritiated methyl- ${ }^{3} \mathrm{H}-$ thymidine $(1 \mu \mathrm{Ci} /$ well $)$ was added after 24 hours of incubation. Cells were harvested on to glass fibre filters 18 hours later. Counts were expressed as counts per minute (cpm).

\section{STATISTICAL METHODS}

The differences between values before and after exposure were tested through the Wilcoxon test. The Spearman's rank correlation coefficients $\left(r_{\mathrm{s}}\right)$ were used to test the correlation between $\mathrm{kg}$ of pesticides applied and the differences between values of the immunological variables before and after exposure.

\section{Results}

All farmers under investigation showed values before exposure for immunological variables within normal limits (table). After one to 12 days the exposure was stopped, the proportions of circulating $T$ helper cells (CD4), suppressor T cells (CD8), CD8 dim, cytotoxic T lymphocytes (CTL), CD8 cells expressing the surface antigen HLA-DR (CD8-DR), and of NK cells were significantly reduced. Within the same period, NK cell activity and lymphoproliferative response to mitogen stimulations also were significantly reduced (table). No correlation was found between $\mathrm{kg}$ of pesticides applied and the decrease in the percentage of lymphocyte subsets. The correlation between decrease in NK cell activity after exposure and quantity of pesticides used was suggestive of an association, although not significantly $\left(r_{\mathrm{s}}=\right.$ $0 \cdot 47, \mathrm{P}=0.08$ ). Evaluation at 50-70 days after exposure showed that the percentage of

Immunological variables (means (SD)) among 10 farmers before and after exposure to phenoxy herbicides (values after exposure were compared with those before)

\begin{tabular}{|c|c|c|c|}
\hline Variables & $\begin{array}{l}\text { Before } \\
\text { exposure }\end{array}$ & $\begin{array}{l}1-12 \text { days } \\
\text { after exposure }\end{array}$ & $\begin{array}{l}50-70 \text { days } \\
\text { after exposure }\end{array}$ \\
\hline $\begin{array}{l}\text { Leucocytes }\left(\times 19^{9} / 1\right) \\
\text { Lymphocytes }\left(\times 19^{9} / 1\right) \\
\text { T cells }(\%):\end{array}$ & $\begin{array}{l}6.0(1.5) \\
2.0(0.3)\end{array}$ & $\begin{array}{l}6.3(1.8) \\
1.9(0.3)\end{array}$ & $\begin{array}{l}5.7(1.5) \\
1.7(1.5)\end{array}$ \\
\hline $\begin{array}{l}\text { CD3 } \\
\text { CD4 } \\
\text { CD4-DR } \\
\text { CD8 } \\
\text { CD8-DR } \\
\text { CD8 dim } \\
\text { CTL } \\
\text { CD4/CD8 ratio } \\
\text { NK cells (\%) } \\
\text { NK cell activity }\left(\mathrm{LU}_{20} \times 10^{-7} \mathrm{EC}\right) \\
\text { Lymphocyte responses to } \\
\text { mitogenic stimulation: }\end{array}$ & $\begin{array}{c}62.5(6.9) \\
34.0(5.5) \\
10 \cdot 1(2 \cdot 2) \\
26 \cdot 0(5.7) \\
19 \cdot 1(17 \cdot 0) \\
39 \cdot 9(16 \cdot 3) \\
12 \cdot 8(4 \cdot 4) \\
1.4(0.4) \\
15.8(10 \cdot 4) \\
214(155)\end{array}$ & $\begin{array}{c}59 \cdot 7(7 \cdot 4) \\
30 \cdot 0(4 \cdot 4)^{\star} \\
8 \cdot 2(5 \cdot 2) \\
20 \cdot 2(7 \cdot 4)^{\star} \\
5 \cdot 7(2 \cdot 1) \dagger \\
28 \cdot 5(16 \cdot 9)^{\star} \\
7 \cdot 6(4 \cdot 4) \dagger \\
1.8(0 \cdot 8) \\
9 \cdot 8(7 \cdot 0) \dagger \\
100(87) \dagger\end{array}$ & $\begin{array}{c}68 \cdot 8(9 \cdot 3)^{\star} \\
35.9(5 \cdot 5) \\
10.9(3.3) \\
34.6(8 \cdot 2)^{\star} \\
7.8(5 \cdot 9)^{\star} \\
34.8(18 \cdot 9) \\
11.8(6.5) \\
1.2(0 \cdot 8) \\
15.5(10 \cdot 5) \\
155(82)^{\star}\end{array}$ \\
\hline $\begin{array}{l}\text { PHA (cpm) } \\
\text { ConA (cpm) }\end{array}$ & $\begin{array}{l}85385(10374) \\
40454(10374)\end{array}$ & $\begin{array}{l}42631(20993) \dagger \\
18556(9333) \dagger\end{array}$ & $\begin{array}{l}73942(19856)^{\star} \\
30746(14359)^{\star}\end{array}$ \\
\hline
\end{tabular}

$\star \mathrm{P}<0.05 ;+\mathrm{P}<0.01$

$\mathrm{LU}_{20} \times 10^{-7} \mathrm{EC}=$ lytic units 20 for $10^{-7}$ effector cells; cpm = counts per minute.
CD8-DR, NK cell activity, and mitogenic proliferative responses of lymphocytes were still significantly decreased $(P<0.05)$, although the percentage of CD3 and CD8, which were affected immediately after exposure, recovered, showing significant increases.

\section{Discussion}

Experimental studies have shown that different types of pesticides are able to exert a variety of effects on the immune system in animals. ${ }^{18}$ Although human data on that topic are very limited, it has been suggested that immunotoxic effects of pesticides have played a part in cancers related to farming, and more specifically in the aetiopathogenesis of B cell malignancies. 791019

The present study is the first to show immunological changes after short term exposure to phenoxy herbicides in an agricultural setting. According to these preliminary data, commercial formulations of 2,4-D and MCPA are able to exert short lived immunosuppressive effects that decrease immediately after exposure the percentage of lymphocyte subsets CD4, CD8, CD8-DR, CD8 dim, CTL, the percentage of NK cells along with as their activity, and the lymphocyte mitogen responses.

The percentage of CD8-DR was severely reduced after exposure to phenoxy herbicides. The functional role of these cells is still unclear. It has been reported that these lymphocytes are able to inhibit cytotoxic cell activity and release a soluble lectin binding factor as the mediator of their inhibitory activity. ${ }^{20}$ The reduction of the percentage of CTL, NK cells, and NK cell cytotoxic activity reported here is of particular interest. These immune cells are able to recognise virally infected cells and destroy them through cytolytic mechanisms. The NK cells are also considered to be directly involved in cell mediated immunity to tumours. ${ }^{21}$ It has been recently suggested that other types of pesticides - that is, organophosphorous insecticides-might increase the risk of lymphomas through the impairment of cytotoxic mechanisms of immune cells. ${ }^{19}$ Farmers are usually exposed to different types of pesticides, depending on the seasonal crop care in which they are involved. Both phenoxy herbicides and organophosphorous insecticides, applied during different periods of the year, could cause episodes of immunosuppression, specifically affecting NK cell mediated cytotoxicity, perhaps through different mechanisms. One may speculate that prolonged and repeated episodes of immunosuppression might be involved in the lymphomagenesis process. Interestingly, in two epidemiological studies, the risk of NHL increased according to the mean annual number of days spent mixing or applying 2,4-D. ${ }^{26}$

A reduced response of lymphocytes to mitogenic stimulations was also reported in this study. A generalised suppression of the lymphocyte mitogen responses, in the absence of any structural changes in lymphoid organs, was found in mice after in utero exposure to 
pure 2,4-D esters. ${ }^{13}$ On the other hand, lymphocyte mitogen responsiveness was increased in adult mice after subacute exposure. ${ }^{11} 12$

Our findings are based on a longitudinal approach where immunological variables of the subjects under study before exposure were used as reference. Further studies with unexposed comparison groups are needed to confirm our preliminary data and clarify whether these types of immunological changes may have health implications, contributing specifically to cancer aetiology.

We thank Professor Olav Axelson for providing a thorough revision of the manuscript and useful criticisms.

1 Hardell L, Eriksson M, Lenner P, Lundgren E. Malignant lymphoma and exposure to chemicals, especially organic solvents, chlorophenols and phenoxy acids: a casecolvents, chlorophenols and phenoxy acids

2 Hoar SK, Blair A, Holmes FF, Boysen CD, Robel RJ, Hoover $\mathbf{R}$, et al. Agricultural herbicides and risk of Hoover $\mathrm{R}$, et al. Agricultural herbicides and risk of
lymphoma and soft tissue sarcoma. $¥ A M A$ 1986;256: lymphom

3 Woods JS, Polissar L, Severson RK, Heuser LS, Kulander BG. Soft tissue sarcoma. And non-Hodgkin's lymphoma in relation to phenoxyherbicide and chlorinated phenol exposure in western Washington. $\mathcal{F}$ Nattl Cancer Inst 1987;78:899-910.

4 Hardell L, Eriksson M. The association between soft-tissue sarcomas and exposure to phenoxyacetic acids: a new case-referent study. Cancer 1988;62:652-6.

5 Wigle DT, Semenciw RM, Wilkins K, Riedel D, Ritter L, Morrison HI, et al. Mortality of Canadian farm operators: non-Hodgkin's lymphoma mortality and agricultors: non-Hodgkin's lymphoma mortality and agricul-
tural practices in Saskatchewan. F Natl Cancer Inst 1990;

6 Zahm SH, Weisenburger DD, Rabbitt PA, Saal CR, Vaught JB, Cantor PK, et al. A case-control study of nonHodgkin's lymphoma and the herbicide 2,4 dichlorophenoxyacetic acid $(2,4-D)$ in eastern Nebraska. Epidemiology 1990;1:349-56.

7 Kelly SJ, Guidotti TL. Phenoxyacetic acid herbicides and chlorophenols and the etiology of lymphoma and soft tissue neoplasms. Public Health Rev 1989-90;17:1-37.
8 Kinlen LJ. Immunosuppression and cancer. In: Vanio H, Magee PN, McGregor DB, McMichael AJ, eds. Mechanisms of carcinogenesis in risk identification. Lyon: International Agency for Research on Cancer, 1992: 237-53.

9 Vineis P, D'Amore P, and the Working Group on the Epidemiology of Hematolymphopoietic Malionancies in Italy. The role of occupational exposure and immun deficiency in B-cell malignancies. Epidemiology 1992;3: 266-70.

10 Blair A, Zahm SH, Pearce NE, Heineman EF, Fraumeni JF. Clues to cancer aetiology from studies of farmers. Scand $\mathcal{F}$ Work Environ Health 1992;18:209-15.

11 Blakley BR, Schiefer BH. The effect of topically applied nbutylester of 2,4-dichlorophenoxyacetic acid on the immune response in mice. $\mathcal{F}$ Appl Toxicol 1986;6:291-5.

12 Blakley BR. The effects of oral exposure to the N-butylester of 2,4-dichlorophenoxyacetic acid on immune response in mice. Int $\mathcal{F}$ Immunopharmacol 1986;8:93-9.

13 Blakley BR, Blakley PM. The effect of prenatal exposure to the n-butylester of 2,4-dichlorophenoxyacetic acid $(2,4-$ D) on the immune response in mice. Teratology 1986; 33:15-20.

14 Blakley BR, Gagnon JM. The effect of a commercial 2,4-D formulation on chemical- and viral-induced tumor production in mice. $\mathcal{F}$ Appl Toxicol 1992;12:245-9.

15 Adams SL Horvat ST, Irwin AE, Junkin RW, Koreman NM, Blakley BR. The effects of Tordon 202C exposure on urethane-induced lung adenoma formation in female CD-mice. Vet Hum Toxicol 1991;33:209-11.

16 Seaman WE, Gindhart TD, Blackman MA, Dalal B, Talal $N$, Werb $Z$. Suppression of natural killing in vitro by monocytes and polymorphonuclear leukocytes. $\mathcal{F}$ Clin Invest 1982;69:876-8.

17 Herberman RB, Bartam S, Haskill JS, Nunn M, Holden HT, West WH. Fc receptors on mouse effectors cells mediating natural cytotoxicity against tumor cells. $\mathfrak{f}$ Immunol 1977;119:322-6.

18 Thomas PT, Busse WW, Kerkvliet NI, Luster MI, Munson AE, Murray M, et al. Immunologic effects. In: Baker SR, Wilkinson CF, eds. The effects of pesticides on human Wealth. Advances in Modern Environmental Toxicology vol health. Advances in Modern Environmental Toxicology vol 19 Newcombe DS. Immune surveillance, organophosphorus exposure, and lymphomagenesis. Lancet 1992;339:539-41. 20 Sadat-Sowti B, Debre P, Idziorek T, Guillon J-M, Hodida F, Okzenhendler E, et al. A Lectin-binding soluble released by $\mathrm{CD8}^{+} \mathrm{CD} 57^{+}$lymphocytes from AIDS patients inhibits T cell cytotoxicity. Eur 7 Immunol 1990; 21:737-41.

21 Trichieri G. Biology of natural killer cells. Adv Immunol 1989;47:187-376.

\section{Rejected manuscripts}

From February 1994, authors whose submitted articles are rejected will be advised of the decision and one copy of the article, together with any reviewers' comments, will be returned to them. The fournal will destroy remaining copies of the article but correspondence and reviewers' comments will be kept. 